\title{
Mitochondrial D-loop DNA analyses of Norway Lobster (Nephrops norvegicus) reveals genetic isolation between Atlantic and Mediterranean populations
}

\author{
JEANNE GALLAGHER ${ }^{1 *}$, JOHN A. FINARELLI ${ }^{1}$, JÓNAS P. JONASSON²${ }^{2}$, JENS CARLSSON $^{1}$ \\ ${ }^{1}$ School of Biology and Environmental Science/Earth Institute, University College Dublin, Belfield, \\ Dublin 4, Ireland \\ ${ }^{2}$ Marine and Freshwater Research Institute, Skúlagata 4, 101 Reykjavík, Iceland \\ *Corresponding author: tel: +353-(0)1 716-2197, jeanne.gallagher@ucdconnect.ie
}

Nephrops norvegicus is a commercially valuable demersal fisheries species. Relatively little is understood about this species' population dynamics across its distribution with previous mitochondrial and microsatellite studies failing to identify significant population-level differentiation. In this study, sequence variation in the mitochondrial (mtDNA) D-loop was analysed from samples across the distribution range. Analysis of a $375 \mathrm{bp}$ fragment of the $D$-loop revealed significant genetic differentiation between samples from the northeast Atlantic and the East Mediterranean $\left(F_{S T}=0.107, P<0.001\right)$. Tau $(\tau)$, theta $\left(\vartheta_{0}\right.$ and $\left.\vartheta_{1}\right)$ and $F u$ 's $F_{S}$ values suggest the species spread between 10,500 to 19,000 ybp and subsequently expanded rapidly across the Atlantic.

Keywords: Genetic structure, mitochondrial DNA, control region, phylogenetics, Atlantic, Mediterranean, glacial refugia.

\section{INTRODUCTION}

Nephrops norvegicus (Linnaeus, 1758) is a benthic-dwelling, decapod crustacean, which inhabits burrows in patches of soft muddy sediment between approximately 4 to $800 \mathrm{~m}$ depth (Holthius, 1991; Johnson et al., 2013). The species' distribution ranges from Iceland and northern Norway, in the North Atlantic Ocean, to Morocco and the Mediterranean in the south (Figure 1) (Maltagliati et al., 1998; Bell et al., 2006; Johnson et al., 2013). Nephrops norvegicus is dioecious, with mating occurring following a brief courtship shortly after females moult (Powell and Eriksson, 2013). Females produce between 900-6000 eggs in a brood (Powell and Eriksson, 2013), with dispersal occurring in the larval phase, which can last up to fifty days (Hill, 1990; Dickey-Collas et al., 2000). Survival of the larvae depends on a combination of factors including suitable temperature, food availability and access to suitable substrate (Dickey-Collas et al., 2000; Aguzzi and Sardà, 2008; Pochelon et al., 2009). Upon settling juveniles occupy or create burrows to avoid predation (Powell and Eriksson, 2013). Adult $N$. norvegicus do not migrate or leave their mud-patch at any point (Aguzzi and Sardà, 2008).

Commonly sold as Norway lobster, Dublin Bay prawn, scampi or langoustine, $N$. norvegicus is a commercially important fisheries species (Thorpe et al., 2000) with the most recent global landing estimates at 54,000 tonnes in 2014 (FAO; Thorpe et al., 2000). Within the EU, $2017 \mathrm{~N}$. norvegicus landings are estimated to be worth over $€ 165$ million (Marine Institute, 2017). For management purposes the species is currently divided into approximately forty geographic 
D-loop analyses of Nephrops norvegicus

groups, known as functional units (FU's) and geographical survey areas (GSA's), across its distribution (Relini et al., 1999; Ungfors et al., 2013).

Effective management relies on accurate and reliable information on how species are distributed over time and space. Current assessment of $N$. norvegicus is largely based on underwater video surveys (Johnson et al., 2013; Marine Institute, 2016). Although the species has a relatively long larval stage (fifty days), the low mobility of adults may increase the vulnerability of stocks to local overfishing relative to other highly mobile commercial species. Commercial fishing has been suggested as the principal driver of population dynamics for the species (Thorpe et al., 2000). Despite the substantial economic value of $N$. norvegicus fisheries, there is limited knowledge of the species' genetic population structure and whether it aligns with existing functional, biological or management units (Stamatis et al., 2006).

Population genetics has proven highly suited for identifying biological populations by quantifying the connectivity (gene flow/isolation) among them. Population genetics can also assess vital demographic parameters, such as effective population size, evolutionary history and recent demographic expansion (Beissinger and McCullough, 2002). Mitochondrial DNA (mtDNA) has several advantages in population genetic studies. For example, as a maternally-inherited, haploid marker there is a lack of genetic recombination which is ideal for studying deep historical population dynamics (Held et al., 2016). Zane et al. (2000) used single strand conformation polymorphism analyses of mtDNA in populations of Northern krill, Meganyctiphanes norvegica (M. Sars, 1857) to reveal at least three distinct populations in the North-East Atlantic. Yuhara et al. (2014) utilised mtDNA Cytochrome c oxidase subunit I (COI) analyses to clarify the genetic diversity and connectivity among local coastal populations of the saltmarsh sesarmid crab, Clistocoeloma sinense (Shen, 1933) around the Japanese coastline.

With respect to $N$. norvegicus, allozyme analyses on 110 individuals from one Scottish and two Mediterranean localities (Aegean Sea and Adriatic Sea) failed to reveal genetic differentiation (Passamonti et al., 1997). Maltagliati et al. (1998) performed allozyme analyses with fifteen enzyme systems in $N$. norvegicus, examining one Atlantic and eight Mediterranean samples, with approximately 100 individuals from each site. While genetic variability was detected, there was no evident population structure. Stamatis et al. (2006) used ten allozymes systems to investigate samples from the North Sea and the Aegean Sea, finding no significant genetic differentiation among 366 examined individuals. Streiff et al. (2001) did not recover evidence for population structure among forty individuals from two Portuguese locations for five microsatellite loci. Stamatis et al. (2004) performed a restriction fragment length polymorphism analysis on mitochondrial COI DNA segments in 370 individuals, and reported significant but low levels of genetic differentiation, but no structure between the Mediterranean Sea and Atlantic Ocean. Recent population expansion after the Last Glacial Maximum (LGM) was proposed as an explanation. Similarly, no population genetic structure was found using twelve microsatellite loci on 549 individuals from a small geographic range around Iceland (Pampoulie et al., 2011).

Previous studies have yet to recover population differentiation either across the geographic range of $N$. norvegicus, or at finer scales. The mtDNA D-loop has proven hypervariable in other crustacean species with high levels of polymorphism that can be used to discriminate amongst 
D-loop analyses of Nephrops norvegicus

populations (Mcmillen-Jackson and Bert, 2003; 2004). The current study explores the efficacy of this region to determine the presence of population structure across a subsample of the species' distribution.

\section{MATERIALS AND METHODS}

\section{Sampling}

Samples were collected from commercial fishing or research vessels from across the geographic distribution of $N$. norvegicus, including Iceland, Northern Norway, Skagerrak, North Sea, Irish Sea, Porcupine bank, Bay of Biscay, Gulf of Cadiz and Ancona in the Adriatic Sea (Figure 1). Sex and length were recorded, and first and second pereiopods were removed from each individual before being stored in $80 \% \mathrm{EtOH}$. Whole samples that were collected were stored at $-20{ }^{\circ} \mathrm{C}$ before tail tissue was removed and stored in $80 \% \mathrm{EtOH}$. Both males and females ( 2:1) with carapace lengths encompassing an equal number $(n=15)$ of individuals of two length groups (6$35 \mathrm{~mm} \& 35-70 \mathrm{~mm}$ ) were selected to minimise the risk of only including a single cohort that could cause family effects and skew the genetic data (Haynes et al., 2016).

\section{DNA Analysis}

Total genomic DNA was extracted using a modified chloroform/isoamyl alcohol protocol (Petit et al., 1999). Primers (NN3DF 5'-ACA GCG TTA AGA YAC CAT AG-3' and NnDR 5'-GCT CTC ATA AAC GGG GTA TGA-3') were designed initially using Primer-3 as implemented in Geneious ${ }^{\circledR} 7$ (https://www.geneious.com, Kearse et al., 2012) and the D-loop N. norvegicus mitochondrial genome (GenBank Accession: LN681403.1). The resulting amplicons were relatively larger ( $\sim 880 \mathrm{bp}$ ) than had been designed for ( $\sim 600 \mathrm{bp})$ and were sequenced to discover a $\sim 280 \mathrm{bp}$ fragment of the D-loop area missing from within the GenBank data (Appendix 1). Subsequently, new primers JG2 F 5'-CTA CAG ATT TCG TCT ATC AAC-3' and NnD R 5'-GCT CTC ATA AAC GGG GTA TGA-3' were designed on these returning sequences to incorporate the newly discovered $\sim 280 \mathrm{bp}$ for a $\sim 680 \mathrm{bp}$ amplicon. Primer sequences specificity was confirmed using BLAST (Basic Logical Alignment Search Tool; Zhang et al., 2000). Optimal annealing temperature was determined using a gradient PCR.

PCR amplifications were performed in a Biometra T3000 thermocycler (Biolabo, SA) with lid temperature of $95^{\circ} \mathrm{C}$, using a thermal cycling profile of initial heating of $95^{\circ} \mathrm{C}$ for $2 \mathrm{~min}$, followed by 30 cycles of $95^{\circ} \mathrm{C}$ for $30 \mathrm{~s}, 61.2^{\circ} \mathrm{C}$ for $30 \mathrm{sec}$, and $72^{\circ} \mathrm{C}$ for $1 \mathrm{~min}$, followed by a final extension step of $72^{\circ} \mathrm{C}$ for $2 \mathrm{~min}$. Completed reactions were held at $4^{\circ} \mathrm{C}$. PCR products were visualised on $1.5 \%$ agarose gels to verify amplifications, and purified using ExoSap-IT (Affymetrix Ltd., Santa Clara, CA) prior to Macrogen sequencing.

\section{Data and Statistical analyses}

Forward and reverse sequences were aligned and edited in Geneious ${ }^{\circledR} 7.0$, using the $K 80$ substitution model (Kimura, 1980), as determined in JMODELTEST, version 2.1.4. (Guindon and Gascuel, 2003; Darriba et al., 2012). Spatial Analysis of Molecular Variance, SAMOVA 2.0 
D-loop analyses of Nephrops norvegicus

(Dupanloup et al., 2002) was used to define groups of populations which are geographically homogenous and maximally differentiated from each other. Analysis of Molecular Variance (AMOVA) (Excoffier et al., 1992) was performed in ARLEQUIN V3.5 (Excoffier and Lischer, 2010) to generate $F$-statistics, $\Phi_{S T}, \theta$, and $(\tau)$, the $K 80$ substitution model and 10100 replicates. Fu's $F_{s}$ tests whether mutations are selectively neutral. Theta $(\theta)$ is defined as $2 N \mu$ for haploid mitochondrial DNA, where $N$ is the effective population size and $\mu$ is mutation rate per sequence per generation ( $\mathrm{Fu}, 1997)$. Tau $(\tau)$ can measure relative time since a population expansion using $T=\tau / 2 u$, where $u$ is per-nucleotide rate of mutation multiplied by the number of nucleotides in the sequence (Gaggiotti and Excoffier, 2000). Harpending's raggedness index (Harpending, 1994) and mismatch distributions $(S D D)$ were both used to test whether the data deviated significantly from a population expansion model. DNASP version 6.10.01 (Rozas et al., 2017) was used to calculate haplotype $(h)$ and nucleotide diversity $(\pi)$ and to estimate and the nearest neighbour statistic $S_{n n}$ (Hudson, 2000) with 10000 permutations. This statistic uses a symmetric island model on haplotype data to measure sequential 'neighbours' from the same geographical space. In all cases involving multiple comparisons, significance levels were adjusted for multiple tests using the sequential Bonferroni correction technique (Rice, 1989). A map of $N$. norvegicus haplotypes was constructed using POPART (Leigh and Bryant, 2015). An Unweighted Pair Group Method with Arithmetic Mean (UPGMA) dendrogram of $\Phi_{\text {ST }}$ pairwise distance values was created in PAST (Hammer et al., 2001). All software was used with default setting unless specified otherwise.

\section{RESULTS}

\section{DNA Analysis}

Sequence alignments were trimmed for maximum length and quality using individual sequence chromatograms. Only regions of the D-loop for which both forward and reverse strands yielded unambiguous sequences were included for a fragment of $375 \mathrm{bp}$. Of the 270 sequenced samples, 13 were excluded due to poor quality sequence reads. A total of 15 haplotypes were resolved (GenBank Accession: xxxxxx) with nucleotide diversity $(\pi)$ ranging from 0.008 in the Gulf of Cadiz to 0.019 in the Bay of Biscay, and haplotype diversity ranged from 0.508 in Breiðamerkurdjúp to 0.859 in the Bay of Biscay (Table 1). Frequency and location of the haplotypes were displayed on a haplotype map (Figure $2 \mathrm{~A}$ ).

\section{Data and Statistical analyses}

\section{POPULATION DIFFERENTIATION}

The SAMOVA analysis indicated that the best-supported $F_{C T}$ value $\left(F_{C T}=0.109\right)$ was achieved when the samples were clustered into two groups. The first group contained only individuals derived from the Mediterranean (Anacona) while the second group comprised of individuals from all other sampled areas (Table 2).

An AMOVA analysis, using the SAMOVA structure and the K80 distance model (Kimura, 1980) revealed significant heterogeneity among the nine samples $\left(\Phi_{S T}=0.107, \mathrm{P}<0.001\right)$. Withinsample variation accounted for $88.86 \%$ of the variance $\left(\mathrm{F}_{\mathrm{CT}}=0.100, \mathrm{P}<0.001\right)$ (Table 3). Pairwise $\Phi_{\text {ST }}$ values revealed population structure between the eastern Mediterranean (Anacona) sample 
D-loop analyses of Nephrops norvegicus

and each of the eight other samples from the North Atlantic (Table 4). Significant pairwise $\Phi_{\text {ST }}$ values ranged from 0.057 (Anacona/Porcupine) to 0.152 (Anacona/Breiđamerkurdjúp) (Table 4). The nearest-neighbour statistic $\left(S_{n n}\right)$ indicated a significant association between sequence similarity and geographical location $\left(S_{n n}=0.1250, P=0.032\right)$. A UPGMA dendrogram was constructed using sample pairwise $\Phi_{\text {ST }}$ values to visualise genetic distances (Figure $2 B$ ).

\section{POPULATION EXPANSION}

Demographic analyses in ARLEQUIN showed pronounced differences between $\theta_{0}$ and $\theta_{1}$ suggesting rapid population expansion in all samples, with less pronounced differences in the Anacona sample (Table 1). All Fu's $F_{s}$ values were negative and deviated significantly from zero. Mismatch distributions differed significantly from the distributions expected under population expansion in four of the nine sample sites (Table 1). Harpending's raggedness index ranged from 0.040 to 0.138 from the Anacona to the Irish Sea respectively and was significant for all except the Anacona sample (Table 1).

Using the population expansion formula $\mathrm{T}=\tau / 2 \mathrm{u}$, with $\mathrm{u}=\mu \mathrm{k}$, where $\mu=$ per nucleotide substitution rate and $k=$ sequence length population expansion times were estimated between 10,500 to $19,000 \mathrm{ybp}$. Due to the uncertainty around the point estimate of $\tau$ in the Arlequin analyses, 1000 bootstrap replicates were performed drawing random values for tau from between 2.5 and 97.5 percentiles returned by Arlequin. Population expansion times were estimated using $\mu=19 \% / \mathrm{My}$ from the penaeid prawn and pink shrimp D-loop mutation rate (Mcmillen-Jackson and Bert, 2003;2004). From the 1000 bootstrap iterations the mean estimate and upper and lower two standard deviation confidence intervals were calculated (Table 5).

\section{DISCUSSION}

This study recovered a previously-undocumented $280 \mathrm{bp}$ segment of the $N$. norvegicus mitochondrial genome (GenBank Accession: xxxxx). In addition, genetic structure between North Atlantic and Mediterranean Sea N. norvegicus samples was detected in the mtDNA D-loop region. While an Atlantic-Mediterranean divide has been recorded for many highly mobile species (Bargelloni et al., 2003; Carlsson et al., 2004; Farrell et al., 2016), it has not been previously reported for $N$. norvegicus.

Eleven haplotypes are shared among multiple $N$. Norvegicus samples, with four haplotypes unique to a single sample: two unique haplotypes are found in the Bay of Biscay, and one each are found in Breiđamerkurdjúp and Anacona. SAMOVA revealed distinct population genetic differences between the Atlantic samples and the eastern Mediterranean sample, and the nearest neighbour statistic $\left(\mathrm{S}_{n n}\right)$ suggests a significant association between D-loop sequence similarity and geographic location. Average $\Phi_{S T}$ estimates are at least twice as large between the Mediterranean sample and each Atlantic sample than the estimates among all of the Atlantic samples. This suggests that the eastern Mediterranean sample is genetically differentiated from the Atlantic samples. A UPGMA cluster analysis on the $\Phi_{\text {ST }}$ distance matrix demonstrated that the largest genetic differentiation exists between the Mediterranean and all other samples.

Negative $\mathrm{Fu} \mathrm{F}_{\mathrm{s}}$ values suggest recent demographic expansion (Fu, 1997), and the large difference between $\theta_{0}$ and $\theta_{1}$ for all Atlantic sites suggests rapid population expansion. In contrast, the 
D-loop analyses of Nephrops norvegicus

difference in theta values for the Mediterranean sample are two orders of magnitude smaller. When considered with the non-significant Raggedness index, this suggest a less pronounced population expansion in the Mediterranean.

Estimates of time since expansion ranged from 10,500 to $19,000 \mathrm{ybp}$. Large confidence intervals around all of the point estimates for the expansion time overlap, indicating that expansion likely occurred within the same time-frame for all sampled locations. These time estimates are in agreement with those for the LGM in Europe (16,000 to 31,000 ybp, Ashton et al., 2010), and likely represent population expansion into newly available habitat as the ice retreated. Observed haplotype diversity was highest in Bay of Biscay, suggesting this region represents a potential glacial refugium for the Atlantic distribution of the species. The area north of the Bay of Biscay has previously been hypothesized as a refugium for other marine species (e.g., the common mussel Mytilus edulis, (Linnaeus, 1758), Śmietanka et al., 2014), and these results also support species distribution models for several other marine invertebrates, including the common starfish, Asterias rubens (Johnston, 1836), amphipod crustacean Gammarus duebeni (Liljeborg, 1852), flat periwinkle Littorina obtusata (Linnaeus, 1758), dogwhelk Nucella lapillus (Linnaeus, 1758) and barnacle Semibalanus balanoid (Linnaeus, 1767) around the LGM (Waltari and Hickerson, 2013).

This study is the first to reveal a significant genetic differentiation between Atlantic and Mediterranean samples of $N$. norvegicus. These results support a post-glacial expansion, with Atlantic $N$. norvegicus continuing to expand rapidly. In terms of commercial fisheries management, these results do not support current management practices, as no significant genetic differentiation was found among Atlantic samples that cross several functional units. However, these results are important for management within the eastern Mediterranean, as populations experiencing isolation can be more vulnerable to commercial over-exploitation and more difficult to recover in the event of population collapse.

\section{ACKNOWLEDGEMENTS}

We would like to thank the scientists and researchers from the Irish Marine Institute, Ifremer, Marine Research Institute Iceland, Spanish Institute of Oceanography, ISMAR Institute of Marine Sciences, Havforskningsinstituttet Norwegian Institute of Marine Research, Marine Scotland and AFBI for the collection and donation of samples involved in this study. We would also like to thank E. Farrell for his assistance and comments on the manuscript.

\section{FINANCIAL SUPPORT}

J.G. acknowledges funding from the Irish Research Council (IRC) (GOIPG/2015/2977). This project has received funding from the European Union's Horizon 2020 research and innovation programme under Grant agreement No. 678760 (ATLAS). This output reflects only the author's view and the European Union cannot be held responsible for any use that may be made of the information contained therein. 
bioRxiv preprint doi: https://doi.org/10.1101/258392; this version posted February 2, 2018. The copyright holder for this preprint (which was not certified by peer review) is the author/funder. All rights reserved. No reuse allowed without permission.

D-loop analyses of Nephrops norvegicus

\section{REFERENCES}

Aguzzi, J., Sardà, F. (2008) A history of recent advancements on Nephrops norvegicus behavioral and physiological rhythms. Reviews in Fish Biology and Fisheries 18, 235-248. https://doi.org/10.1007/s11160-007-9071-9 
Ashton, N., Lewis, S., Stringer, C. (2010). The Ancient Human Occupation of Britain. Elsevier.

Bargelloni, L., Alarcon, J.A., Alvarez, M.C., Penzo, E., Magoulas, A., Reis, C., Patarnello, T. (2003). Discord in the family Sparidae (Teleostei): divergent phylogeographical patterns across the Atlantic-Mediterranean divide. Journal of Evolutionary Biology 16, 1149-1158. https://doi.org/10.1046/j.14209101.2003.00620.x

Beissinger, S.R., McCullough, D.R. (2002) Population Viability Analysis. University of Chicago Press.

Bell, M.., Redant, F., Tuck, I. (2006) Nephrops Species, in: Phillips, B.F. (Ed.), Lobsters: Biology, Management, Aquaculture and Fisheries. Blackwell Pub, Oxford, UK ; Ames, Iowa.

Carlsson, J., McDowell, J.R., DíAz-Jaimes, P., Carlsson, J.E.L., Boles, S.B., Gold, J.R., Graves, J.E. (2004) Microsatellite and mitochondrial DNA analyses of Atlantic bluefin tuna (Thunnus thynnus thynnus) population structure in the Mediterranean Sea: Population Genetics of Mediterranean Bluefin Tuna. Molecular Ecology 13, 3345-3356. https://doi.org/10.1111/j.1365294X.2004.02336.x

Darriba, D., Taboada, G.L., Doallo, R., Posada, D. (2012) jModelTest 2: more models, new heuristics and parallel computing. Nature Methods 9, 772-772. https://doi.org/10.1038/nmeth.2109

Dickey-Collas, M., Briggs, R.P., Armstrong, M.J., Milligan, S.P. (2000) Production of Nephrops norvegicus larvae in the Irish Sea. Marine Biology 137, 973-981. https://doi.org/10.1007/s002270000404

Dupanloup, I., Schneider, S., Excoffier, L. (2002) A simulated annealing approach to define the genetic structure of populations. Molecular Ecology 11, 2571-2581. https://doi.org/10.1046/j.1365-294X.2002.01650.x

Excoffier, L., Lischer, H.E.L. (2010) Arlequin suite ver 3.5: A new series of programs to perform population genetics analyses under Linux and Windows. Molecular Ecology Resources 10, 564-567. https://doi.org/10.1111/j.17550998.2010.02847.x

Excoffier, L., Smouse, P.E., Quattro, J.M. (1992) Analysis of molecular variance inferred from metric distances among DNA haplotypes: application to human mitochondrial DNA restriction data. Genetics 131, 479-491.

FAO FishFinder - Web Site. About FAO FishFinder. FI Institutional Websites. In: FAO Fisheries and Aquaculture Department [online]. Rome. Updated 12 January 2017. [Cited 22 January 2018]. http://www.fao.org/fishery/

Farrell, E.D., Carlsson, J.E.L., Carlsson, J. (2016) Next Gen Pop Gen: implementing a high-throughput approach to population genetics in boarfish (Capros aper) for fish stock identification. Proceedings of the Royal Society Open Science DOI: $10.1098 /$ rsos.160651.

Fu, Y.X. (1997) Statistical tests of neutrality of mutations against population growth, hitchhiking and background selection. Genetics 147, 915-925.

Gaggiotti, O.E., Excoffier, L. (2000) A simple method of removing the effect of a bottleneck and unequal population sizes on pairwise genetic distances. Proceedings of the Royal Society B: Biological Sciences 267, 81-87.

Guindon, S., Gascuel, O. (2003) A simple, fast, and accurate algorithm to estimate large phylogenies by maximum likelihood. Systematic Biology 52, 696-704. 
Hammer, Ø., Harper, D.A.T., Ryan, P.D. (2001) PAST: Paleontological statistics software package for education and data analysis. Palaeontologia Electronica 1, 9pp.

Harpending, H.C. (1994) Signature of ancient population growth in a low-resolution mitochondrial DNA mismatch distribution. Human Biology 66, 591-600.

Haynes, P.S., Browne, P., Fullbrook, L., Graham, C.T., Hancox, L., Johnson, M.P., Lauria, V., Power, A.M. (2016) Growth in Nephrops norvegicus from a tagrecapture experiment. Scientific Reports 6, 35143. https://doi.org/10.1038/srep35143

Held, C., Koenemann, S., Schubart, C.D. (2016) Phylogeography and Population Genetics in Crustacea. CRC Press.

Hill, A.E. (1990) Pelagic dispersal of Norway lobster Nephrops norvegicus larvae examined using an advection-diffusion-mortality model. Marine ecology progress series. Oldendorf 64, 217-226.

Holthius, L.B. (1991) FAO species catalogue. Vol.13. Marine Lobsters of the World. An annotated and illustrated catalogue of marine lobsters known to date. FAO Fisheries Synopsis. No. 125, Vol. 13. Rome, FAO. 292.

Hudson, R.R. (2000) A New Statistic for Detecting Genetic Differentiation. Genetics 155, 2011-2014.

Johnson, M.P., Lordan, C., Power, A.M. (2013) Habitat and ecology of Nephrops norvegicus. Advances in Marine Biology 64, 27-63. https://doi.org/10.1016/B978-0-12-410466-2.00002-9

Kearse, M., Moir, R., Wilson, A., Stones-Havas, S., Cheung, M., Sturrock, S., Buxton, S., Cooper, A., Markowitz, S., Duran, C., Thierer, T., Ashton, B., Meintjes, P., Drummond, A. (2012) Geneious Basic: An integrated and extendable desktop software platform for the organization and analysis of sequence data. Bioinformatics 28, 1647-1649. https://doi.org/10.1093/bioinformatics/bts199

Kimura, M. (1980) A simple method for estimating evolutionary rates of base substitutions through comparative studies of nucleotide sequences. Journal of Molecular Evolution. 16, 111-120.

Leigh, J.W., Bryant, D. (2015) popart: full-feature software for haplotype network construction. Methods in Ecology and Evolution 1 6, 1110-1116. https://doi.org/10.1111/2041-210X.12410

Maltagliati, F., Camilli, L., Biagi, F., Abbiati, M. (1998) Genetic structure of Norway lobster, Nephrops norvegicus (L.)(Crustacea: Nephropidae), from the Mediterranean Sea. Scientia Marina 62, 91-99.

Marine Institute, (2017) The Stock Book 2017: Annual Review of Fish Stocks in 2017 with Management Advice for 2018. Marine Institute.

Marine Institute (2016) The Stock Book 2016 : Annual Review of Fish Stocks in 2016 with Management Advice for 2017. Marine Institute.

McMillen-Jackson, A.L., Bert, T.M. (2004) Genetic Diversity in the mtDNA Control Region and Population Structure in the Pink Shrimp Farfantepenaeus Duorarum. Journal of Crustacean Biology 24, 101-109. https://doi.org/10.1651/C-2372

Mcmillen-Jackson, A.L., Bert, T.M. (2003) Disparate patterns of population genetic structure and population history in two sympatric penaeid shrimp species (Farfantepenaeus aztecus and Litopenaeus setiferus) in the eastern United 
States: Population Genetics of Two Sympatric Shrimp. Molecular Ecology 12, 2895-2905. https://doi.org/10.1046/j.1365-294X.2003.01955.x

Pampoulie, C., Skirnisdottir, S., Hauksdottir, S., Olafsson, K., Eiriksson, H., Chosson, V., Hreggvidsson, G.O., Gunnarsson, G.H., Hjorleifsdottir, S.

(2011) A pilot genetic study reveals the absence of spatial genetic structure in Norway lobster (Nephrops norvegicus) on fishing grounds in Icelandic waters. ICES Journal of Marine Science 68, 20-25. https://doi.org/10.1093/icesjms/fsq165

Passamonti, M., Mantovani, B., Scali, V., Froglia, C. (1997) Allozymic Characterization of Scottish and Aegean Populations of Nephrops Norvegicus. Journal of the Marine Biological Association of the United Kingdom 77, 727735. https://doi.org/10.1017/S0025315400036158

Petit, E., Excoffier, L., Mayer, F. (1999) No Evidence of Bottleneck in the Postglacial Recolonization of Europe by the Noctule Bat (Nyctalus noctula). Evolution 53, 1247-1258. https://doi.org/10.1111/j.1558-5646.1999.tb04537.x

Pochelon, P.N., Calado, R., Dos Santos, A., Queiroga, H. (2009) Feeding Ability of Early Zoeal Stages of the Norway Lobster Nephrops norvegicus (L.). The Biological Bulletin 216, 335-343. https://doi.org/10.1086/BBLv216n3p335

Powell, A., Eriksson, S.P. (2013) Reproduction: Life Cycle, Larvae and Larviculture, in: Advances in Marine Biology. Elsevier, pp. 201-245.

Relini G., Bertrand J., Zamboni A. (1999) Sintesi delle conoscenze sulle risorse da pesca dei fondi del Mediterraneo centrale (Italia e Corsica). Synthesis of the knowledge on bottom fishery resources in Central Mediterranean (Italy and Corsica). Biologia Marina Mediterranea, 6 (suppl.1): 868 pp.

Rice, W.R. (1989) Analyzing Tables of Statistical Tests. Evolution 43, 223-225. https://doi.org/10.1111/j.1558-5646.1989.tb04220.x

Rozas, J., Ferrer-Mata, A., Sánchez-DelBarrio, J.C., Guirao-Rico, S., Librado, P., Ramos-Onsins, S.E., Sánchez-Gracia, A. (2017) DnaSP 6: DNA Sequence Polymorphism Analysis of Large Data Sets. Molecular Biology and Evolution https://doi.org/10.1093/molbev/msx248

Śmietanka, B., Burzyński, A., Hummel, H., Wenne, R. (2014) Glacial history of the European marine mussels Mytilus, inferred from distribution of mitochondrial DNA lineages. Heredity 113, 250. https://doi.org/10.1038/hdy.2014.23

Stamatis, C., Triantafyllidis, A., Moutou, K., Mamuris, Z. (2006) Allozymic variation in Northeast Atlantic and Mediterranean populations of Norway lobster, Nephrops norvegicus. ICES Journal of Marine Science 63, 875-882. https://doi.org/10.1016/j.icesjms.2006.01.006

Stamatis, C., Triantafyllidis, A., Moutou, K.A., Mamuris, Z. (2004) Mitochondrial DNA variation in Northeast Atlantic and Mediterranean populations of Norway lobster, Nephrops norvegicus: Mitochondrial DNA variation in Norway Lobster. Molecular Ecology 13, 1377-1390. https://doi.org/10.1111/j.1365294X.2004.02165.X

Streiff, R., Guillemaud, T., Alberto, F., Magalhaes, J., Castro, M., Cancela, M.L. (2001) Isolation and characterization of microsatellite loci in the Norway lobster (Nephrops norvegicus). Molecular Ecology Notes 1, 71-72.

Thorpe, S.J., Sole-Cava, A., Watts, P. (2000) Exploited marine invertebrates: genetics and fisheries. Hydrobiologia 420, 165-184. 
D-loop analyses of Nephrops norvegicus

Ungfors, A., Bell, E., Johnson, M.L., Cowing, D., Dobson, N.C., Bublitz, R., Sandell, J. (2013) Nephrops Fisheries in European Waters, in: Advances in Marine Biology Elsevier, pp. 247-314. https://doi.org/10.1016/B978-0-12410466-2.00007-8

Waltari, E., Hickerson, M.J. (2013) Late Pleistocene species distribution modelling of North Atlantic intertidal invertebrates. Journal of Biogeography 40, 249-260. https://doi.org/10.1111/j.1365-2699.2012.02782.x

Yuhara, T., Kawane, M., Furota, T. (2014) Genetic Population Structure of Local Populations of the Endangered Saltmarsh Sesarmid Crab Clistocoeloma sinense in Japan. PLoS ONE 9, e84720. https://doi.org/10.1371/journal.pone.0084720

Zane, L., Ostellari, L., Maccatrozzo, L., Bargelloni, L., Cuzin-Roudy, J., Buchholz, F., Patarnello, T. (2000) Genetic differentiation in a pelagic crustacean (Meganyctiphanes norvegica: Euphausiacea) from the North East Atlantic and the Mediterranean Sea. Marine Biology 136, 191-199.

Zhang, Z., Schwartz, S., Wagner, L., Miller, W. (2000) A greedy algorithm for aligning DNA sequences. Journal of Computational Biology 7, 203-214. https://doi.org/10.1089/10665270050081478 
D-loop analyses of Nephrops norvegicus

Table 1. Mitochondrial sequence variability in the D-loop for $N$. norvegicus from the nine sample sites; number of individuals $(n)$, number of haplotypes $(n h)$, haplotype diversity $(h)$, nucleotide diversity $(\pi)$, tau $(\tau)$, theta for times 0 and $1\left(\theta_{0}\right.$ and $\left.\theta_{1}\right)$, Fu's $F_{s}$, Harpending's Raggedness index (Hri), and sum of squared differences from mismatch analyses (SSD)

\begin{tabular}{|c|c|c|c|c|c|c|c|c|c|c|}
\hline Collection & $n$ & $n h$ & $h$ & $\pi$ & $\tau$ & $\theta_{0}$ & $\theta_{1}$ & Fu's $F_{S}$ & Hri & SSD \\
\hline Anacona & 28 & 4 & 0.616 & 0.009 & 2.5 & 0 & 11.055 & $-26.691 *$ & 0.040 & 0.006 \\
\hline Bay of Biscay & 24 & 10 & 0.859 & 0.019 & 2.2 & 0 & 6829.96 & $-26.832 *$ & 0.062 & 0.006 \\
\hline Breiđamerkurdjúp & 30 & 7 & 0.508 & 0.010 & 2.8 & 0 & 6834.96 & $-26.748 *$ & 0.055 & 0.010 \\
\hline Gulf of Cadiz & 30 & 5 & 0.556 & 0.008 & 1.6 & 0 & 3429.40 & $-27.522 *$ & 0.079 & 0.006 \\
\hline Irish Sea & 29 & 7 & 0.643 & 0.018 & 1.6 & 0 & 3424.39 & $-27.717^{*}$ & 0.138 & 0.022 \\
\hline Northern Norway & 30 & 6 & 0.582 & 0.009 & 1.7 & 0 & 6844.37 & $-27.165^{*}$ & 0.090 & 0.010 \\
\hline North Sea & 26 & 5 & 0.689 & 0.012 & 2 & 0 & 6829.96 & $-26.775^{*}$ & 0.091 & 0.011 \\
\hline Porcupine & 30 & 8 & 0.722 & 0.013 & 2.5 & 0 & 6834.96 & $-26.647^{*}$ & 0.046 & 0.003 \\
\hline Skagerrak & 30 & 8 & 0.729 & 0.015 & 3 & 0 & 3414.98 & $-26.344^{*}$ & 0.050 & 0.007 \\
\hline
\end{tabular}

Values in bold are significant at $\mathrm{P}<0.05,{ }^{*} \mathrm{P}<0.001$

Table 2. SAMOVA results table for $N$. norvegicus. $K$ corresponds to the number of populations. Optimal $\mathrm{F}_{\mathrm{CT}}$ and groupings $(\mathrm{K}=2)$ are highlighted in bold.

\begin{tabular}{lll}
\hline Groups (K) & Structure Recovered & $\mathrm{F}_{C T}$ \\
\hline $\mathbf{2}$ & [AN][BOB, BRE,GC,IS,NN,NS,POR,SKA] & $\mathbf{0 . 1 0 9 2}$ \\
3 & {$[\mathrm{AN}][\mathrm{BOB}][\mathrm{BRE}, \mathrm{GC}, \mathrm{IS}, \mathrm{NN}, \mathrm{NS}, \mathrm{POR}, \mathrm{SKA}]$} & 0.0799 \\
4 & {$[\mathrm{AN}][\mathrm{POR}][\mathrm{BRE}, \mathrm{GC}, \mathrm{IS}, \mathrm{NN}, \mathrm{SKA}][\mathrm{BOB}][\mathrm{NS}]$} & 0.0717 \\
5 & {$[\mathrm{POR}][\mathrm{BRE}, \mathrm{IS}][\mathrm{BOB}][\mathrm{AN}][\mathrm{GC}, \mathrm{NN}, \mathrm{NS}, \mathrm{SKA}]$} & 0.0661 \\
6 & {$[\mathrm{BRE}, \mathrm{IS}][\mathrm{AN}][\mathrm{GC}, \mathrm{NN}, \mathrm{NS}][\mathrm{SKA}][\mathrm{POR}][\mathrm{BOB}]$} & 0.0618 \\
7 & {$[\mathrm{AN}][\mathrm{BRE}, \mathrm{IS}][\mathrm{POR}][\mathrm{NN}][\mathrm{GC}, \mathrm{NS}][\mathrm{SKA}][\mathrm{BOB}]$} & 0.0620 \\
8 & {$[\mathrm{SKA}][\mathrm{AN}][\mathrm{NS}][\mathrm{GC}][\mathrm{BOB}][\mathrm{NN}][\mathrm{BRE}, \mathrm{IS}][\mathrm{POR}]$} & 0.0637 \\
\hline
\end{tabular}

Table 3. AMOVA table of temporal and spatial genetic variation of $N$. norvegicus from sites sampled

\begin{tabular}{lllll}
\hline AMOVA & & & & \\
Source of variation & \% of variance & Fixation indexes & F-statistics & $P$ \\
\hline Among groups & 10.00 & 0.126 & FSC & $<0.001$ \\
Among samples within groups & 1.14 & 0.111 & FST & 0.785 \\
Within populations & 88.86 & 0.100 & FCT & 0.000 \\
\hline
\end{tabular}


D-loop analyses of Nephrops norvegicus

Table 4. Pairwise $\Phi_{\text {ST }}$ estimates (below diagonal) for D-loop mtDNA data among $N$. norvegicus samples. P-values (upper diagonal) in bold were significant after Sequential Bonferroni correction (initial $\alpha=0.05 / 8=0.00625$ ).

\begin{tabular}{cccccccccc}
\hline Population & \multirow{2}{*}{ Anacona } & $\begin{array}{c}\text { Bay of } \\
\text { Biscay }\end{array}$ & $\begin{array}{c}\text { Breiđamer- } \\
\text { kurdjúp }\end{array}$ & $\begin{array}{c}\text { Gulf of } \\
\text { Cadiz }\end{array}$ & $\begin{array}{c}\text { Irish } \\
\text { Sea }\end{array}$ & $\begin{array}{c}\text { Northern } \\
\text { Norway }\end{array}$ & $\begin{array}{c}\text { North } \\
\text { Sea }\end{array}$ & Porcupine & Skagerrak \\
\hline Anacona & & $\mathbf{0 . 0 1 9}$ & $<\mathbf{0 . 0 0 1}$ & $\mathbf{0 . 0 2 1}$ & $\mathbf{0 . 0 2 4}$ & $\mathbf{0 . 0 3 1}$ & $\mathbf{0 . 0 4 6}$ & $\mathbf{0 . 0 2 6}$ & $\mathbf{0 . 0 1 6}$ \\
Bay of Biscay & 0.111 & & 1.336 & 1.134 & 0.270 & 0.870 & 1.062 & 0.273 & 0.717 \\
Breiðamerkurdjúp & 0.152 & 0.046 & & 0.572 & 0.615 & 0.627 & 0.200 & 0.060 & 0.670 \\
Gulf of Cadiz & 0.144 & 0.002 & 0.019 & & 1.196 & 1.434 & 1.356 & 0.140 & 0.704 \\
Irish Sea & 0.143 & 0.043 & -0.009 & 0.005 & & 0.403 & 0.333 & 0.240 & 0.604 \\
Northern Norway & 0.072 & 0.018 & 0.011 & -0.006 & -0.001 & & 1.248 & 1.554 & 0.748 \\
North Sea & 0.087 & -0.007 & 0.043 & -0.015 & 0.027 & -0.010 & & 0.358 & 0.625 \\
Porcupine & 0.057 & 0.049 & 0.061 & 0.051 & 0.037 & -0.010 & 0.015 & & 0.129 \\
Skagerrak & 0.098 & -0.014 & 0.002 & -0.010 & -0.008 & -0.010 & -0.009 & 0.020 &
\end{tabular}

Table 5. Estimated expansion times for $N$. norvegicus with upper and lower two standard deviation confidence intervals.

\begin{tabular}{cccccccccc}
\hline & Anacona & $\begin{array}{c}\text { Bay of } \\
\text { Biscay }\end{array}$ & $\begin{array}{c}\text { Breiðamer- } \\
\text { kurdjúp }\end{array}$ & $\begin{array}{c}\text { Gulf of } \\
\text { Cadiz }\end{array}$ & Irish Sea & $\begin{array}{c}\text { Northern } \\
\text { Norway }\end{array}$ & North Sea & Porcupine & Skagerrak \\
\hline + 2 SD & $31,875.41$ & $26,006.56$ & $26,329.73$ & $17,736.93$ & $18,207.28$ & $18,834.99$ & $21,034.19$ & $23,777.64$ & $27,923.24$ \\
& & & & & & & & & \\
Mean & $19,049.10$ & $16,038.80$ & $17,035.32$ & $10,499.87$ & $10,765.61$ & $11,470.40$ & $13,057.05$ & $15,458.56$ & $18,240.16$ \\
& & & & & & & & & \\
- 2 SD & $12,635.90$ & $11,054.92$ & $12,388.11$ & $6,881.34$ & $7,044.77$ & $7,788.11$ & $9,068.48$ & $11,299.02$ & $13,398.62$
\end{tabular}




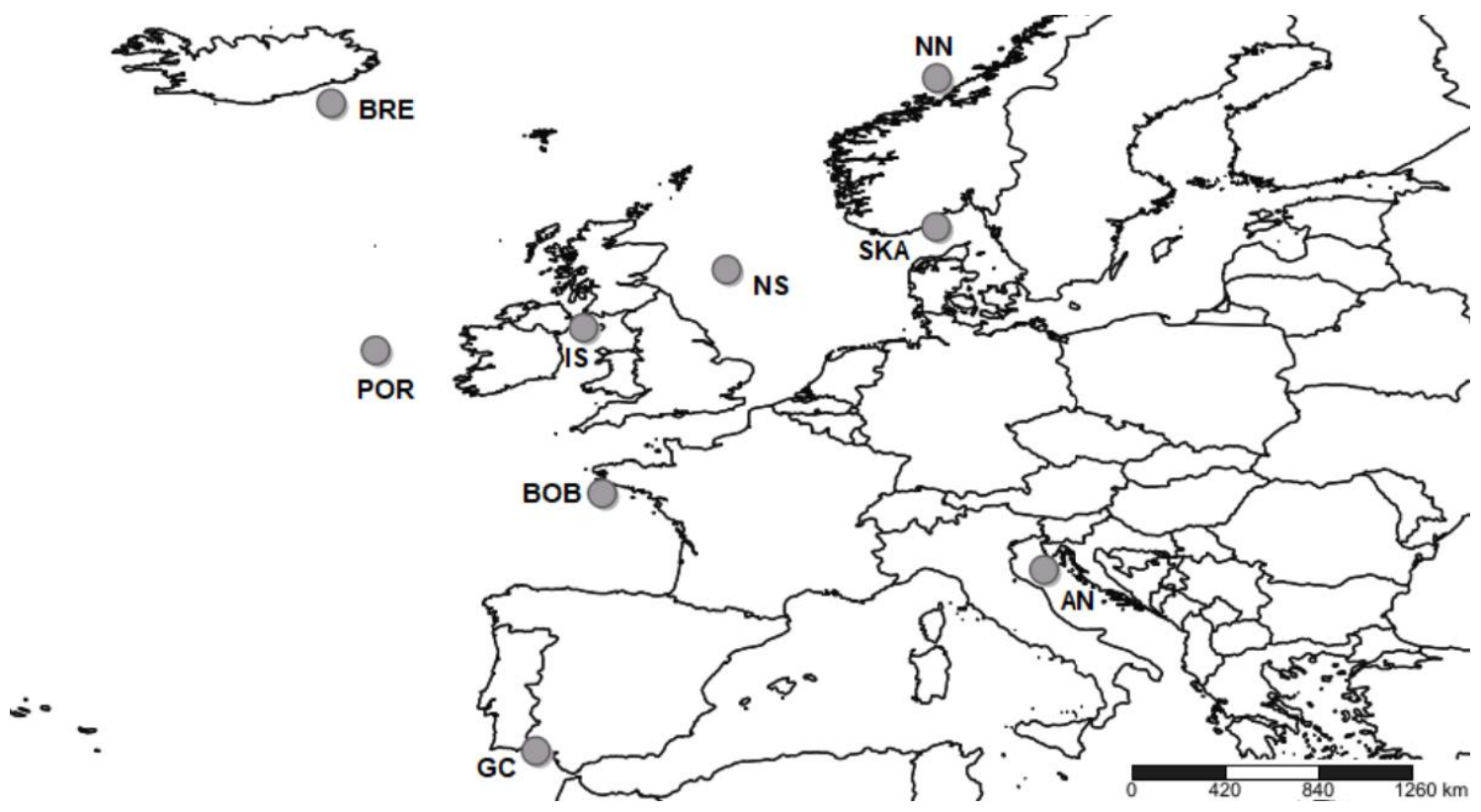

Figure 1. Nine sample locations ( $n=30$ per locality) for $N$. norvegicus mtDNA D-loop analyses. AN: Anacona, BOB: Bay of Biscay, BRE: Breiðamerkurdjúp, GC: Gulf of Cadiz, IS: Irish Sea (West), NN: Northern Norway, NS: North Sea, POR: Porcupine, SKA: Skagerrak 
bioRxiv preprint doi: https://doi.org/10.1101/258392; this version posted February 2, 2018. The copyright holder for this preprint (which was not certified by peer review) is the author/funder. All rights reserved. No reuse allowed without permission.

\section{D-loop analyses of Nephrops norvegicus}

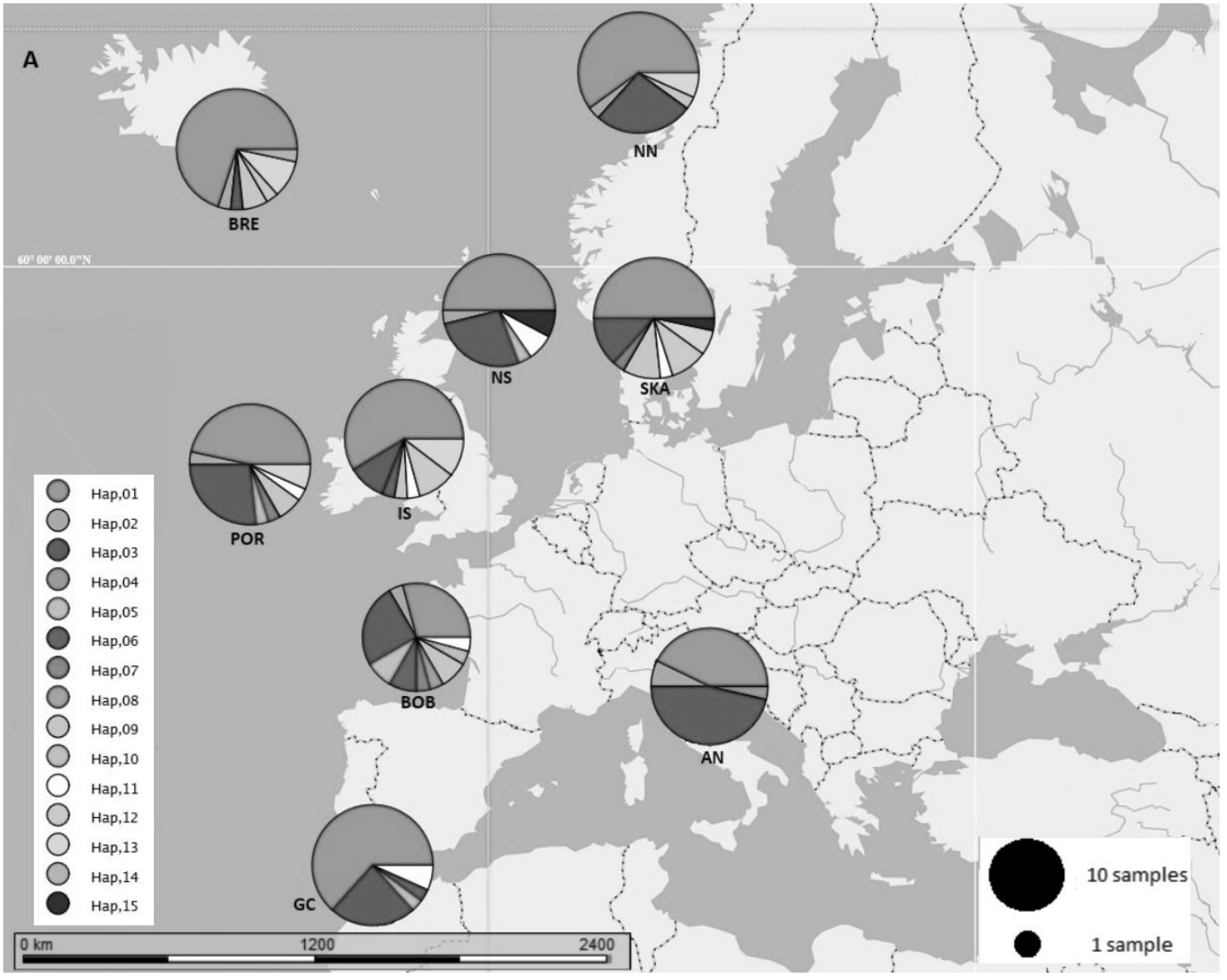

B

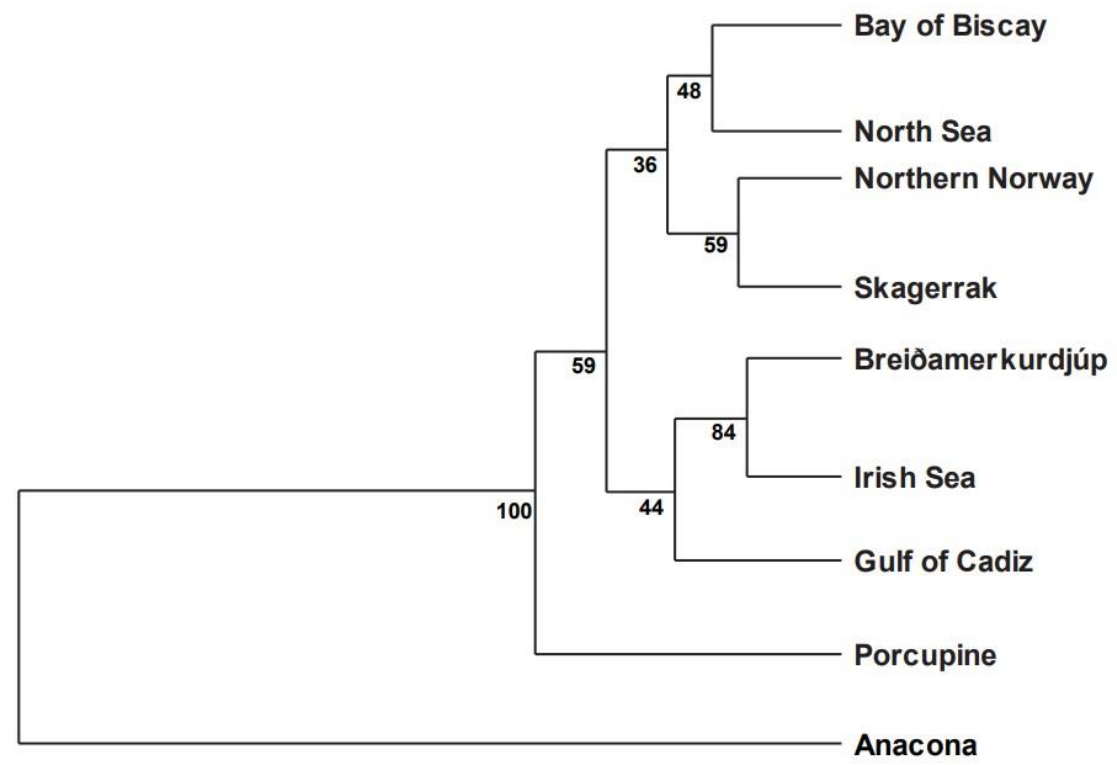


D-loop analyses of Nephrops norvegicus

Figure $2 \mathrm{~A}$ and 2 B. 2A: Map of the geographic distribution and frequency of haplotype groups in nine sample sites of N. norvegicus. AN: Anacona, BOB: Bay of Biscay, BRE: Breiðamerkurdjúp, GC: Gulf of Cadiz, IS: Irish Sea (West), NN: Northern Norway, NS: North Sea, POR: Porcupine, SKA: Skagerrak haplotypes. 2B: UPGMA dendrogram based on $\Phi_{\text {ST }}$ pairwise distance values calculated from frequency data of 15 haplotypes. 
D-loop analyses of Nephrops norvegicus

\title{
Appendices
}

\section{Appendix 1.}

Nephrops norvegicus D-loop sequence (GenBank Accession: $x x x x x$ ) with 280bp fragment (shown in bold) missing from within the GenBank data.

\begin{abstract}
ATATACACAGATCAGTAAAAATATATTTTTAAGGTAATCTAAAAAGTAAACTTATATAATTTCATT GAAATTCATTACARTCTGAAAGTCAATGATTTAATTTTATAAATCGACTAAATAAGATCTATAAATA АААТСTTAССССTTСAAAGGTCAСTTTCTCCTGAGGGGAGCTCССTTTTCCCAACGGGGTAAGATT TCTATTGGGAGAGCAGGATTATAATTATAGAGAGTTGGGTATAAGGCTTCATTGTTTACACATATAT АСТАTTAАATTAАTTATATACATTTATATGTATATATATATATATATATATACTATTTAAАTAАTAT

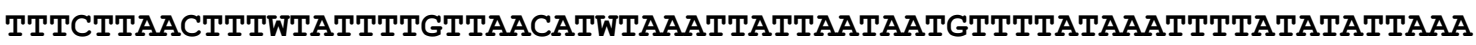
ATAAAATACAGTAAAAAAGTTTTTAGATAAATTTCTACGAATATTATACTATTATACACAATGGAA TTCCACCAATTCTTTAAAGATCAAAACTTTTCGTGCCGTTTACACTAGTATACAAAAGAGAAGCTAA TTCTAAGCTAATGG
\end{abstract}

